\title{
A Bacterial Machinery for Surface Displayed Enzymes
}

\author{
Yüzeyde Gösterilen Enzimler İçin Bakteriyel Bir Mekanizma
}

\author{
Research Article \\ Urartu Özgür Şafak Şeker \\ Bilkent University, UNAM- Institute of Materals Science and Engineering, National Nanotech. Res. Center, Ankara, Turkey.
}

\section{A B STR ACT}

iomaterial based protein delivery systems have been utilized for many applications in biomedicine. Despite their great success, there is a need to develop innovative living, decision making systems for protein delivery. In this context, here, a cellular system is proposed for protein release and delivery. Such systems can be used not for biomedical purposes but also for other biochemical applications. In this regard a Escherichia coli autotransporter protein, Ag43 was engineered to display on its cell membrane. Using this system alkaline phosphatase protein is displayed on the cell surface as a fusion of Ag43-ALP which is also carrying a specific TEV protease excision site. It was shown that the active from of the enzyme was released upon its interaction with TEV protease from the cell surface. In this study a cellular machinery is proposed to be used as a controlled enzyme delivery system.

\section{Key Words}

Whole cell biocatalysis, autotransporter, synthetic biology.

\section{Ö z}

iyomateryal temelli protein taşıma sistemleri birçok biyotıp uygulamasında kullanılmak üzere iyileştirildi. Büyük başarılarına rağmen yenilikçi ve karar verme mekanizmasına sahip sistemlere protein taşınmasında hala intiyaç duyulmaktadır. Bu çalışmada protein salınımı ve taşınması için hücresel bir sistem tasarlanmıştır. Bu sistemler sadece biyotıp uygulamalarında değil, aynı zamanda diğer biyokimyasal sistemler için de uyarlanabilir. Bu bağlamda bir Escherichia coli oto-taşıyıcı protein, Ag43 hücre zarında gösterilmek üzere tasarlanmıştır. Alkali fosfataz proteinli bu sistem kullanılarak Ag43 ve özellikli TEV proteaz kesme bölgesi taşıyan ALP'nin birleşmesi gösterilmiştir. Enzimin aktif formunun hücre yüzeyinden salgılanan TEV proteaz ile iletişimi sonucunda salındığı açıklanmıştır ve bu makalede kontrollü enzim taşıma sistemini sağlayan bir hücresel mekanizma önerilmiştir.

\section{Anahtar Kelimeler}

Tüm hücre biyokatalizi, oto-taşıyıcı, sentetik biyoloji.

Article History: Received: Feb 25, 2018; Revised: Mar 03, 2018; Accepted: Mar 05, 2018; Available Online: Mar 26, 2018.

DOI: $10.15671 /$ HJBC.2018.238

Correspondence to: U.Ö.Ş. Şeker, Bilkent Uni., UNAM-Ins. of Mat. Sci. and Eng., National Nanotech. Res. Center, Ankara, Turkey. 


\section{INTRODUCTION}

- nzymes are critical molecules for many - biomedical and biotechnological applications their engineering and structural control is critical for their functions [1]. Generally purified forms of the enzymes are being used, however, their immobilized versions are also popular in many industrial settings [2]. Additionally, instead of using pure enzymes, bacterial machines for whole cell biocatalysts can be designed and used [3]. In such applications cells can be programmed as a whole cell biocatalyst using specific genetic circuits. In most of the whole cell biocatalyst applications enzymes are expressed intracellularly [4,5] However there is a need to display such enzymes on the cell surfaces to accommodate them for extracellular activities. In the case of the bacteria there is a limited number of opportunities to display enzymes in an active, and intact form on the cell surface. Despite many available surface displayed systems, autotransporter systems are very promising to display enzymes and proteins on the cell surfaces [6-8].

Autrotransporters are specific membrane proteins. These proteins are displaying functional polypeptides on the cell membrane. These systems are promising as engineered cell surface display systems. Among those Ag43 protein in Escherichia coli is under great interest due to its phase variable behaviours and controlled protein secretion capability [9]. Ag43 is coded by flu gene in E. coli genome. Ag43 is synthesized as a chain of 1039 amino acids. Dam methylase and OxyR global regulator control the expression of the Ag43 protein [10-12]. In it was found that the Ag43 protein has 50000 copies when it is expressed $[13,14]$. Ag43 protein does not need any specific chaperone proteins for folding as it can carry out also a chaperone function as well. Initially Ag43 protein is synthesized as a form of a single chain, however these whole chain is processed into alpha and beta subunits. Alpha subunit of the protein assembles in to the cell membrane and upon its integration into the cell membrane it forma beta barrel structure, which leads a pore formation. The remaining part of the protein namely the beta subunit forms is transferred to the outer space of the cell and remained attached to the cell membrane through its interaction with alpha-subunit embedded to the cell membrane. $[15,16]$ The interaction between the subunits is not very tight and mediated by the non-covalent interactions. The interaction between alpha and beta subunits of the Ag43 can be broken by increasing the temperature to $60^{\circ} \mathrm{C}$ [17]. The expression of the $\mathrm{Ag} 43$ protein also triggered the settlement of the cell population through the interaction between the beta subunits of the Ag43 proteins.

Dues do its versatility as a possible cell surface display tool initial attempts made to use Ag43 protein as an surface display of nonnative proteins for $E$. coli however these attempts are limited. Another reason for the Ag43 as an optimal candidate for surface display of the protein is its copy number in E. coli is very high to serve as a surface displaying systems for enzymes compared to the other surface displayed proteins. These makes Ag43 protein as an ideal model cell surface display systems for protein display. Up to date some of the immunological factors and proteins have been displayed on the cell of the $E$. coli using Ag43 protein [18,19].

In this study, a model whole cell biocatalyst system was proposed. Whole cell biosensor has been designed to carry out a certain biocatalysis function by expressing enzyme of interest upon induction of the genetic design to produce and secrete the enzyme. Compared to the conventional catalysis system whole cell catalysis systems are convenient in terms of providing flexibility to display enzymes for a lower cost. In such systems enzymes are attached to the membrane of the cells which enables the users to remove the enzymes easily from the solution by centrifugation. Additionally, cells can be programmed to express the cells at a given time and they can start to secreted the enzymes when they are wanted to act on the substrate. Whole cell catalysis can used to program the cells to secrete multi-enzymes, which means that a heterologous catalysis can be achieved through cellular programming of the cells, while the enzymes are displayed on the cell membrane. In this context cell displayed enzyme systems provide new insights in developing next generation of biocatalysis apparoach with a systems based thinking towards 
creating system biocatalysis. In current work we have engineered $\mathrm{Ag} 43$ protein of $E$. coli to display a well-known, widely used enzyme alkaline phosphatase (named as ALP). Employing the genetic engineering approaches we achieved to display the engineered ALP on the cell membrane of $E$. coli, the activity of the enzymes was noted both when it is displayed on cell membrane and the displayed protein was released from the cell membrane.

\section{MATERIALS and METHODS Cloning of ALP 6H PelB Ag43 160N Pet22b Vector}

The ALP gene with N-terminal $6 x$ His tag and $C$-terminal flexible linker was amplified from $E$. coli DH5 $\alpha$ genome using $\mathrm{P} 1$ and $\mathrm{P} 2$ primers. TEV recognition site was added to ALP gene via PCR using $\mathrm{P} 1$ and $\mathrm{P} 3$ primers. $\mathrm{P} 4$ and $\mathrm{P} 5$ primers was used to amplify the N-terminal truncated $\mathrm{Ag} 43$ gene from $E$. coli DH5 a genome. Truncated Ag43 gene and modified ALP gene was assembled into Ncol-Xhol digested Pet22b vector using Gibson Assembly [20].

P1: 5' GCCGGCGATGGCCATGGGCCACCACCACCACCACCACGGTGGCGGTGGATCCCGGACACCAGAAATGCCTGT 3'

P2: 5' GCCCTGAAAGTACAGGTTTTCGCTACCACCGCCACCTTTCAGCCCCAGAGCGGCTTTC 3

\section{P3: 5'TTTATTGATGGTTGTGCGCTTAAGGCTAC- CACCGCCACCGCCCTGAAAGTACAGGTTTTC 3'}

\section{P4: 5'TCAGTGGTGGTGGTGGTGGTGCTCGAGT-}

\section{CATCAGAAGGTCACATTCAGTG 3}

\section{P5: 5'TTTCAGGGCGGTGGCGGTGGTAGCCTTA- AGCGCACAACCATCAATAAAAACG 3}

Following the cloning of the Ag43 fusion partner, the clones were sent for sequencing the check the alkalinephopsphatase protein sequence identitiy. The alignment results is presented in Figure 2.

\section{Trypsin digestion assay for surface displayed ALP}

Sequence verified construct was transformed into E. coli BL21 (DE3) strain. A single colony was picked from agar plate and inoculated into $5 \mathrm{ml}$ of LB medium with appropriate antibiotics. The overnight grown cells were subcultured 1:100 into $10 \mathrm{ml}$ of fresh LB supplemented with $\% 1(\mathrm{w} / \mathrm{v})$ glucose and antibiotics. At mid log phase $\mathrm{OOD}_{600}$ : 0.4-0.6), the gene was induced with $1 \mathrm{mM} \mathrm{IPTG}$ at $18^{\circ} \mathrm{C}$ for overnight.

\section{Detection of the Alkaline phosphatase enzymatic activity}

Fresh ALP expressed cells were collected and centrifuged at $8000 \mathrm{xg}$ for 5 minutes. Cells were resuspended with $1 \mathrm{x}$ PBS, and stored at $4^{\circ} \mathrm{C}$ for

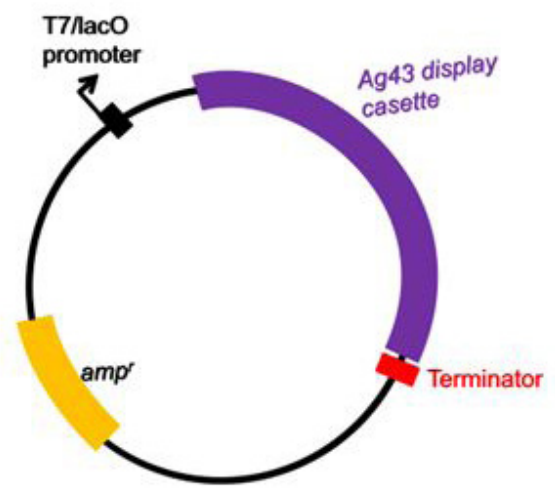

Figure 1. Plasmid map used for the expression of the fusion protein Ag43-ALP.

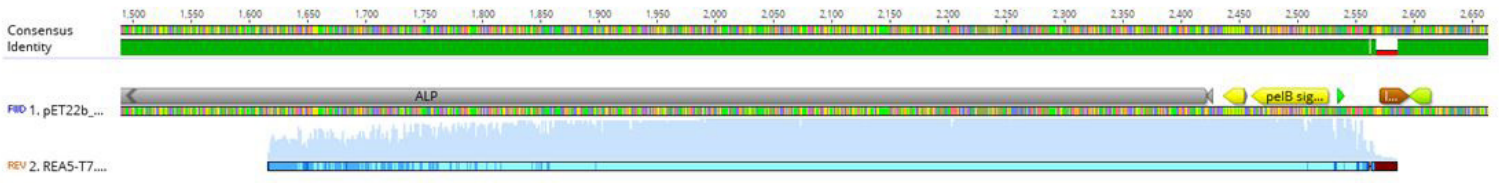

Figure 2. Sequence alignment of the cloned ALP protein. 
further experiments. For trypsin treatment, $5 \times 10^{8}$ cells were taken and suspended with $200 \mu \mathrm{l}$ x PBS. $10 \mu \mathrm{g}$ trypsin protease (Sigma- Aldrich) was added, and incubated $37^{\circ} \mathrm{C}$ for 2 hours. After incubation, cells were centrifuged, and washed twice with $1 x$ PBS. The washed cells were resuspended with 200 $\mu l$ of $p$-nitrophenylphosphate ( $p N P P$ ) substrate solution (Sigma-Aldrich). The resuspended cells were incubated at $37^{\circ} \mathrm{C}$ for 3 hours. Total ALP activity was measured as p-nitrophenol (pNP) absorption at $405 \mathrm{~nm}$.

\section{TEV Protease Accessibility Assay}

$5 \times 10^{8}$ fresh ALP expressed cells were centrifuged and washed with TEV protease buffer $(50 \mathrm{mM}$ Tris- $\mathrm{HCl} \mathrm{pH}=8,0.5 \mathrm{mM}$ EDTA) without DTT. Cells were resuspended in $200 \mu \mathrm{l}$ of TEV protease buffer, and 5 unit of ACTEV protease (Invitrogen) was added. The cleavage reaction was incubated at $4^{\circ} \mathrm{C}$ for overnight. Cells were centrifuged at full speed for 5 minutes. Supernatants were collected. $100 \mu$ l of supernatant after cleavage reaction was mixed with $100 \mu \mathrm{l}$ of PnPP substrate solution. The mixture were incubated at $37 \mathrm{C}$ for 3 hours. Supernatant ALP activity was measured as pNP at $405 \mathrm{~nm}$.

\section{RESULTS}

Enzymes are valuable biocatalysts and they have been heavily used in many areas including biomedicine, fine chemical synthesis. However, generally enzymes are used in their pure form and the cost for the enzymes may cause problems in their co-effectiveness. In this regard, there have been studies to immobilize enzymes and protein on solid supports to provide a longer lifetime and better durability for them [21]. In a whole cell system these optimizations can be achieved through engineering of the cellular genetic regulation systems [22]. In our study we have formed a system where the timely control of the enzyme secretion was achieved through an inducible system. To create such a system Ag43 autotransporter system is engineered. The genetic parts of the Ag43 protein can be found in Figure 3.

The signalling peptide allow the polypeptide chain to be recognised by the cellular machine for transportation. In our design we have included a specific signalling part that is called the tobacco etching virus protease (TEV protease) recognition site. TEV recognition site is added

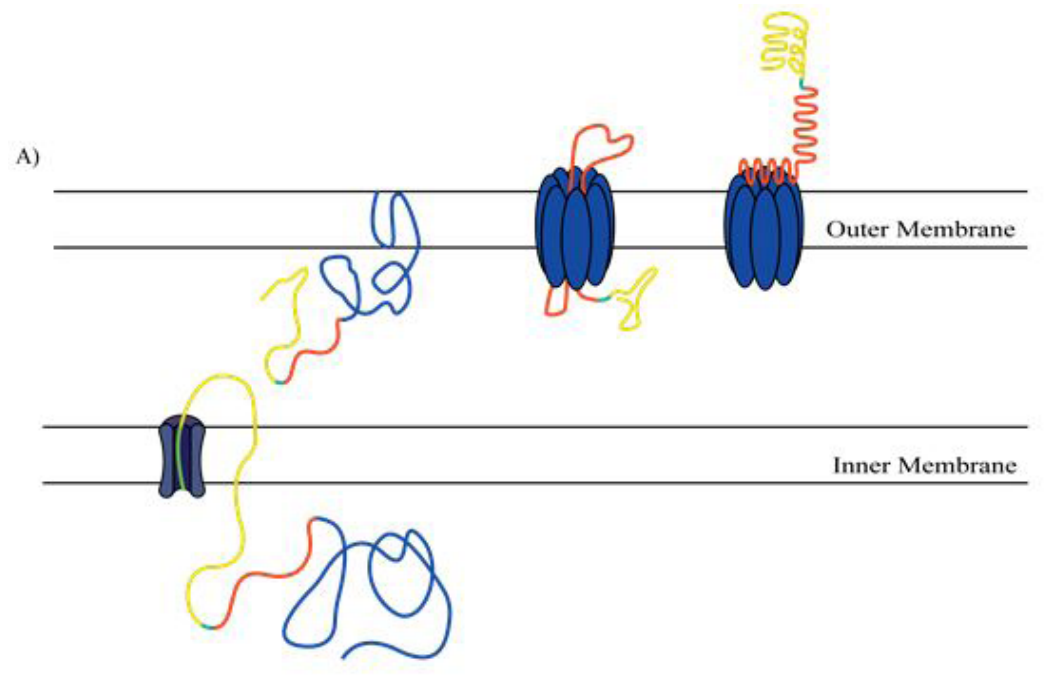

B)

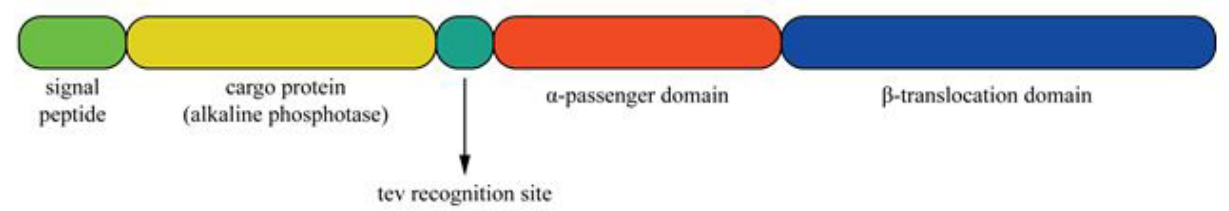

Figure 3. A. The secretion of the Ag43 autotransporter system, the polypeptide chain is translated and transported through the dedicated secretion machinery. The polypeptide chain cleaved and two distinct polypeptide chains are formed, blue polypeptide chain forms a pore on the cell membrane that helps the cargo protein to be transported through the cell membrane. B. The parts of the expressed autotransporter within the cytoplasm. 
to remove the cargo protein after is displayed on the surface of the bacteria. This will allow on to control the release of the protein from the surface of the bacteria at a timely manner. TEV protease has a specific digestion site formed by the following amino acid sequence : (Glu-Asn-LeuTyr-Phe-GIn $\downarrow$ Gly). We have selected the alkaline phosphatase enzyme as the model enzyme to display opn the cell surface and to show its release from the cell membrane upon addition of the TEV protein from the surface of the bacteria.

The gene encoding for the engineered autotransporter system was cloned under the control of a $\mathrm{P}_{\text {Laco }}$ promoter. This promoter is inducible and transformed into E. coli BL21 cell. This cell is suitable for the production of the proteins under the control of the Lacl repression along with pLac promoter system. [22] As descried in materials and methods section the cell were grown and induced to initiate the engineered autotransporter protein expression. Following the expression and folding of the protein the cell membrane of the protein was expected to be displayed on the cell surface. In this study, ALP enzyme was expected to be displayed on the cell surface, and should show enzymatic activity. In order to probe the existence of the ALP and its activity the ALP displaying cell were used to probe enzymatic activity of ALP. ALP enzymatic activity was followed by the breakdown of pNPP substrate as given in materials and methods section. Following the collection of the ALP displaying cells the activity of the cell was measured and data was normalized by cell number, the result of this measurement is given in Fiqure 4. In order to

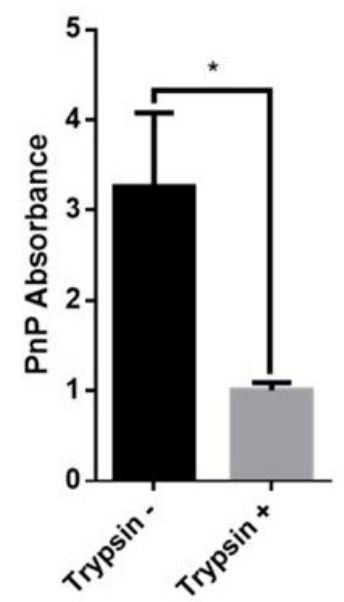

confirm that the protein are displayed on the cell surface, we have used trypsin digestion. Trypsin is a non-specific protease that attacks amino acid sequences without a sequence preference. [24] So, trypsin is a good tool to detect the presence of the displayed protein on the cell surface. During this removal we do expect to see a decrease in the enzymatic activity. As seen on Figure 4 upon trypsin exposure the ALP activity has decrease dramatically.

As stated earlier the removal of ALP from the cell surface is initially tested with trypsin and this protease is attacking the displayed enzymes instead of releasing it from the cell membrabe. After the verification of the ALP display on the cell surface, using trypsin assay we took a step further and decide to do a programmed ALP release from the cell surface using a dedicated protease. The number of specific proteases are limited and one of the best studied one among them is TEV protease. TEV protease can target a specific recognition site and carry out the cleavage of the protein of interest from it fusion partner. We have employed the TEV protease.

In order to propose a programmed release of the ALP from the cell surface, TEV protease was added to the cell suspension. As described in the materials section protease was incubated with the cell suspension and at the end of the incubation the released ALP activity was measured from solution after removing the cells with centrifugation. As seen on Figure 5, the result of the experiments points the release of the intact and functional ALP enzyme. Compared to the initial enzyme activity there is

Figure 4. Trypsin based release of the ALP protein, and activity of the ALP protein before and after trypsin enzyme treatments. The decrease in the enzyme activity is statistically significant ( $t$-test, $p<0.05$ ). 

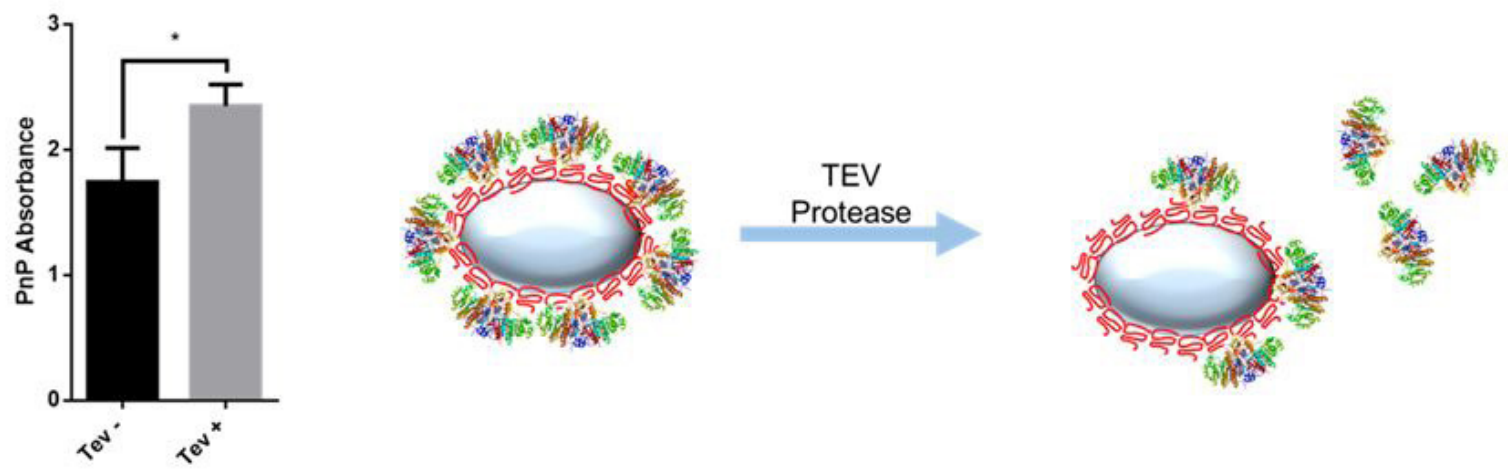

Figure 5. ALP release from the surface of the cells displaying the enzyme upon addition of the TEV protease. The increase in the enzyme activity is statistically significant (t-test, $p<0.05)$.

an increase in the enzyme activity, this because of the unintentionally released of the ALP protein from the $E$. coli periplasmic space. However upon exposure to the TEV protease an obvious increase in the activity of the free enzyme was noted after removing the cells from the solution. Another point that needs to be discussed is the decrease in the enzyme activity in the case of the trypsin addition. Upon addition of the trypsin activity one may expect to see also an increase in the ALP activity in the solution however this was not the case. The main reason for this case is the non-specific nature of the trypsin enzyme. Trypsin enzyme cuts the available protein in a random way which lead the degradation of the enzyme, and finally loss of enzyme activity.

\section{DISCUSSIONS}

Cellular programming for the secretion of enzymes and small molecules is a promising approach to create biological machines to control bioprocesses. In this regard synthetic biology gains more importance and provides new functionalities for cellular programming. In cellular programming innovative genetic switches are needed and these can be utilized as a part of the whole cell biocatalyst systems. In this work the utilization of an autotransporter protein is presented as a tool to display functional enzymes. The design of the genetic construct is critically important to control the release of the displayed enzymes from the cell surface. Using a timely control can provide an opportunity to control a given process conditions at a given time. However, due to the molecular barriers it may not be feasible to use natural display system in the designs for controlled protein release. One of the critical barrier in such work is the docking of the protease of interest to release the displayed protein from the cell surface. In order to prevent such hindrances a specific tag can be used that may allow the protein of interest to be displayed from a distance from the cell surface. In the presented work the system can be enhanced by co-expressing the TEV protease and the enzyme of the interest at the same time from the cell surface. This will give the flexibility not to add the external TEV protease. There is also a need to underline that the choice of the protease is critical to release the protein of interest in an active form. That is why proteases targeting very specific recognition sites should be chosen. To sum up, whole cell biocatalyst systems can be designed and implemented for many diverse applications, including to deliver protein based drug molecules in gut by using probiotics. Such innovative applications will open new avenues for our understanding to develop smart, living drug delivery systems.

\section{ACKNOWLEDGEMENTS}

We thank Recep Erdem Ahan for technical help during the experiments. Dr. Seker acknowledges financial support from TUBA-GEBIP.

\section{References}

1. D.D. Boehr, R.N. D'Amico, N. Rebecca, K.F. O'Rourke, F. Kathleen, Engineered control of enzyme structural dynamics and function, Prot. Sci., 27 (2018) 825-838.

2. C. Silva, M. Martins, S. Jing, J.J. Fu, J. Fu, A. CavacoPaulo, Practical insights on enzyme stabilization, Crit. Rev. Biotechnol., 38 (2018) 335-350.

3. J.H. Schrittwieser, S. Velikogne, M. Hall, Artificial biocatalytic linear cascades for preparation of organic molecules, Chem. Rev., 118 (2018) 270-348. 
4. F. Kazenwadel; M. Franzreb, B.E. Rapp, Synthetic enzyme supercomplexes: co-immobilization of enzyme cascades, Anal. Methods, 7 (2015) 40304037.

5. M. Jeschek, S. Panke, T.R., Artificial metalloenzymes on the verge of new-to-nature metabolism, Trends Biotech. 36 (2018) 60-72.

6. T. Nicolay, J. Vanderleyden, S. Spaepen, Autotransporter-based cell surface display in gramnegative bacteria, Critical Reviews in Microbiology, 41 (2015) 109-123.

7. H. Nakatani, K. Hori, Cell surface protein engineering for high-performance whole-cell catalysts, Frontiers of Chemical Science and Engineering, 1 (2017) 46-57.

8. Decorating microbes: surface display of proteins on Escherichia coli, E. van Bloois, R.T. Winter, H. Kolmar, M.W. Fraaije, Trends in Biotechnology, 29 (2011) 7986.

9. N. Dautin, H. D. Bernstein, Protein secretion in gramnegative bacteria via the autotransporter pathway. Annu. Rev. Microbiol., 61 (2007) 89-112.

10. W. Haagmans, M. van der Woude M., Phase variation of Ag43 in Escherichia coli: Dam-dependent methylation abrogates OxyR binding and OxyRmediated repression of transcription, Mol. Microbiol., 35 (2000) 877-887.

11. D.E. Waldron, P. Owen, C.J. Dorman, Competitive interaction of the OxyR DNA-binding protein and the Dam methylase at the antigen 43 gene regulatory region in Escherichia coli, Mol. Microbiol., 44 (2002) 509-520.

12. A. Wallecha, V. Munster, J. Correnti, T. Chan, M. van der Woude, Dam- and OxyR-dependent phase variation of agn43: essential elements and evidence for a new role of DNA methylation, J. Bacteriol., 184 (2002) 3338-3347.

13. G.C. Ulett, J. Valle, C. Beloin, O. Sherlock, J.M. Ghigo, M. A. Schembri1, Functional analysis of antigen 43 in uropathogenic Escherichia coli reveals a role in longterm persistence in the urinary tract, Infect. Immun., 75 (2007) 3233-3244

14. H. Hasman, T. Chakraborty, P. J. Klemm, Antigen43-mediated autoaggregation of Escherichia coli is blocked by fimbriation, J. Bacteriol., 181(1999) 4834 4841.
15. K. Kjaergaard, M.A. Schembri, H. Hasman, P.J. Klemm, Antigen 43 from Escherichia coli induces inter- and intraspecies cell aggregation and changes in colony morphology of Pseudomonas fluorescens, J. Bacteriol., 182 (2000) 4789-4796.

16. O. Sherlock, U. Dobrindt, J.B. Jensen, R.V. Munk, P. Klemm, Glycosylation of the self-recognizing Escherichia coli Ag43 autotransporter protein, J. Bacteriol., 188 (2006) 1789-1807.

17. K. Kjaergaard, H. Hasman, M.A. Schembri, P. Klemm, Antigen 43-mediated autotransporter display, a versatile bacterial cell surface presentation system, J. Bacteriol., 184 (2002) 4197-4204.

18. F.Y. Huang, C.C. Wang; Y.H. Huang, H.G. Zhao, J.L. Guo, S.L. Zhou, H. Wang, Y.Y. Lin, G.H. Tan, Antigen 43/Fc epsilon 3 chimeric protein expressed by a novel bacterial surface expression system as an effective asthma vaccine, Immunology, 143 (2014) 230-240.

19. I.Munoz-Gutierrez,C.Moss-Acosta,B.Trujillo-Martinez, G. Gosset, A. Martinez, Ag43-mediated display of a thermostable beta-glucosidase in Escherichia coli and its use for simultaneous saccharification and fermentation at high temperatures, Microb. Cell Fact., 13 (2014) 106-

20. D.G. Gibson, L. Young, R.Y. Chuang, J.C. Venter, C.A. Hutchison, H.O. Smith, Enzymatic assembly of DNA molecules up to several hundred kilobases, Nat. Methods, 6 (2009) 343-345.

21. C.W. Lee, S.H. Jang, H. Chung, Improving the stability of cold-adapted enzymes by immobilization, Catalysts, 7 (2017) 112

22. Y. Liu, D.S. Kim, M. Jewett, C. Michael, Repurposing ribosomes for synthetic biology, Curr. Opin. Chem. Biol., 40 (2017) 87-94.

23. R. Lutz, H. Bujard, Independent and tight regulation of transcriptional units in Escherichia coli via the $\mathrm{LacR} / \mathrm{O}$, the TetR/O and AraC/I-1-I-2 regulatory elements, Nucleic Acids Res., 25 (1997) 1203-1210.

24. C. Magni, F. Sessa, J. Capraro, M. Duranti, E. Maffioli, A. Scarafoni, Structural and functional insights into the basic globulin $7 \mathrm{~S}$ of soybean seeds by using trypsin as a molecular probe, Biochem. Biophys. Res. Commun., 496 (2018) 89-94. 